\title{
A review on the recent applications of gluten-free flour, functional ingredients and novel technologies approach in the development of gluten-free bakery products
}

\author{
${ }^{1}$ Ronie, M.E., ${ }^{2}$ Zainol, M.K. and ${ }^{1,{ }^{*}}$ Mamat, H. \\ ${ }^{I}$ Food Technology and Bioprocessing Program, Faculty of Food Science and Nutrition, Universiti Malaysia Sabah, \\ 88400 Kota Kinabalu, Sabah, Malaysia \\ ${ }^{2}$ Faculty of Fisheries and Food Science, Universiti Malaysia Terengganu, 21030, Kuala Nerus, Terengganu
}

\author{
Article history: \\ Received: 9 December 2020 \\ Received in revised form: 18 \\ January 2021 \\ Accepted: 2 April 2021 \\ Available Online: 31 August \\ 2021
}

Keywords:

Gluten-free flour,

Bread,

Biscuit,

Cake

DOI:

https://doi.org/10.26656/fr.2017.5(5).721

\begin{abstract}
Gluten is detrimental to people who suffer from gluten-related disorders. Recently, the upsurge in demand for gluten-free products can be traced not only from the population that suffered from gluten-related disorders but also people who prioritize healthy lifestyles and practising gluten-free diets. One of the most challenging tasks in the development of gluten-free products is their quality. The purpose of this review is to describe the application of gluten-free flours in common bakery products such as bread, cakes, and biscuits. This article does summarize some functional ingredients such as hydrocolloids, protein, and enzymes and also the applications of novel technological approaches including high-pressure treatment, sourdough fermentation and extrusion technology. Overall, different approaches utilized in the improvement of gluten-free bakery products will lead to various quality outcomes.
\end{abstract}

\section{Introduction}

Gluten is a functional ingredient, and it is very wellknown for its viscoelasticity characteristic in various food products (Brockow et al., 2015), especially in bread because it helps in the rising process and development of air bubbles resulting in a porous structure (Woomer and Adedeji, 2020). Besides, gluten proteins are characterized by high proline and glutamine content which has the ability to cross the epithelial barrier and stimulate the immune system subsequently trigger an allergic reaction or autoimmune response such as celiac disease (Ortiz et al., 2017). Therefore, regardless of avoiding raw food containing gluten, gluten-free (GF) consumers have to avoid many more products containing gluten as a functional ingredient.

According to Codex Alimentarius International Food Standards, GF foods can be derived from naturally GF ingredients or any ingredients containing wheat, barley, rye or crossbred varieties of these grains that undergone specific processed in order to remove gluten with a gluten level not exceeding 20 milligrams per kilogram. In general, GF products are designed as a valuable choice for people suffering from gluten-related disorders (GRDs). GRDs comprise three different conditions, to be specific celiac disease, allergy to wheat and non-celiac gluten sensitivity (Roszkowska et al., 2019). In fact, the only effective treatment to avoid triggering the effect of gluten-related disorders is by eliminating any gluten food sources completely out of their diet.

As highlighted by Gujral et al. (2012), the elimination and restriction of gluten from diets have increased dramatically in recent years. The upsurge in demand for GF products can be traced not only from the increased diagnosis of GRDs but as well among consumers who prioritize a healthy lifestyle and exercise on the GF diet since they believed that the GF diet was generally healthier (Croall et al., 2019). To be expected, the consumption of GF products will keep an increase in the future (Forbes, 2015).

Nevertheless, commercially available GF bread are incompetent compared to gluten-containing bread in terms of quality and acceptability (Naqash et al., 2017). This is one of the most challenging tasks in the development of GF products, due to the shortage of alternative ingredients that can imitate the functional properties of wheat protein which are responsible in contributing viscoelasticity in the wheat dough (Roman et al., 2019). As a solution, scientific literature has dealt with the function of few alternate ingredients that capable of improving the GF bakery products, such as alternative starches and flours, hydrocolloids, proteins, enzymes and lipids (Naqash et al., 2017; Roman et al., 2019).

In the present article, the application of alternative 
GF flours for bread, cakes, and biscuits are reviewed. This article also covers the functional ingredients that are typically used in GF bakery products such as hydrocolloids, protein, and enzymes. Finally, the recent novel technologies approach, including the application of the high-pressure treatment, sourdough fermentation and extrusion technology that have been implemented in the production of GF bakery products were also focused on this article.

\section{Gluten-free flour used in bakery products}

\subsection{Gluten-free bread}

In recent years, there have been several studies have focused on the application of pigmented rice flour in the development of GF bread (Thiranusornkij et al., 2018; Gusmão et al., 2019; Thiranusornkij et al., 2019). The reason to choose pigmented rice flour is due to its good source of phytochemical compounds and good eating quality (Kraithong et al., 2018). On the other hand, another GF cereal such as millet is also used for making GF bread. Nevertheless, Habiyaremye et al. (2017) have revealed that millet has an undesirable effect on the final product due to its astringent flavour and somehow because of its poor functional properties of the protein, however according to Tomić et al. (2019) incorporation of proteins and enzymes can improve the technical quality of it. Furthermore, GF bread made from sorghum usually produces small volume and brittle crumb bread (Schober et al., 2005). According to Trappey et al. (2014), this is due to the inability of protein content in sorghum to set structure in bread.

Besides, another alternative GF flour is made from pseudocereals. Liu et al. (2019) reported that the addition of amaranth in GF bread has shown to improve the water holding capacity, viscoelasticity, and micronutrient contents. In addition, Southgate et al. (2017) analysed that buckwheat capable of enhancing the quality of bread in terms of insoluble fibre content, specific volume, cell's circularity of bread loaves, cells number and most important it does not affect the sensory properties of the final product.

Despite the few types of flour mentioned above, legumes such as chickpea and soybean are also potential ingredients in the development of GF bread. In general, chickpea is rich in protein and contain essential amino acids (glutathione), vitamins, minerals, dietary fibre (Yamsaengsung et al., 2010) and phenolic compounds (Xiao et al., 2014) which can increase nutrients in GF bread. However, some drawbacks that were observed on the quality of chickpea bread are typically related to losses in volume and poor bread texture (Yamsaengsung et al., 2010; Ragaee et al., 2011). As well as soybean flour, it has been proved that this flour is rich in protein, vitamins ( $\mathrm{A}, \mathrm{B}, \mathrm{C}$ and $\mathrm{D}$ ) and minerals (calcium and phosphorus) (Serrem et al., 2011). A study conducted by Taghdir et al. (2017) has shown that the addition of $15 \%$ soybean flour successfully enhanced the quality of bread, sensory properties as well as nutritional profile of the final product.

\subsection{Gluten-free cakes}

In the bakery industry, a cake can be categorized into two groups known as (1) angel and sponge cakes and (2) layer and pound cakes (Itthivadhanapong and Sangnark, 2016). Generally, rice flour is one of the ingredients that can be used to substitute wheat flour in the making of GF cakes. The study conducted by de la Hera et al. (2012) found that the finest particles of rice flour are capable of producing batters with low specific volume, small and uniform bubbles. In general, low specific volume batters will lead to the cake with high volume and symmetry index. Nevertheless, in the study of Itthivadhanapong and Sangnark (2016), the authors reported that the substitution of black glutinous rice flour had increased the specific gravity, lower the specific volume and overall had greater firmness, gumminess and chewiness compared to a cake made from wheat flour. Buckwheat is another GF cereal that has been studied in the making of GF cakes. According to Levent and Bilgiçli (2011), high addition of buckwheat flour in the range of $15 \%$ to $20 \%$ capable of improving the uniformity and symmetry index of the cake, but adversely affected the softness of the crumb.

As well as lupin flour, one of the legume source flour is also studied by the same authors, Levent and Bilgiçli (2011) reported that the volume and softness of the cakes could be enhanced by incorporating $20 \%$ of lupin flour. In addition, it has the ability to improve crust yellowness and significantly increases the protein content, fat, and mineral contents of the final products. On the other hand, Dhen et al. (2016) has reported that the quality of GF cakes capable of being improved with the usage of soy flour, to be specific the quality of final products is affected by the usage quantity and size particle of the flour. Generally, soy flour successfully decreased the hardness and slowed down the rate of staling during storage.

Apart from that, pseudocereals are another group of good GF sources that can be used in the making of GF cakes. The previous study by Bozdogan et al. (2019) has reported that the addition of $50 \%$ quinoa flour has successfully improved the batter stability, homogeneity, mechanical strength, nutritional and sensory properties, improved specific volume as well as the viscosity of the batter with the increasing usage of quinoa flour. Moreover, Shevkani et al. (2015) explained that quinoa flour is able to bind more water compared to potato and rice starch hence resulting in an increment of the viscosity value. This is due to the higher protein content 
in quinoa flour that could lead to the increment of viscosity value (Turkut et al., 2016). Other than that, amaranth flour is another potential GF source that can be used in the development of GF cakes. In the-recent study conducted by Estiri and Naghipour (2019), it has been investigated that $20 \%$ amount of amaranth flour plus $0.5 \%$ mandab gum had presented the highest specific volume, porosity, improved moisture content and lowest firmness for 2 hours and within one-week storage period.

\subsection{Gluten-free biscuits}

The replacement of wheat flour with GF flour in biscuits is a lot easier compared to bread due to the incidental role of gluten. In recent years, there has been increasing interest in the study on the effect of composite GF flours in the development of biscuits. Man et al. (2014) reported that it is relevant to blend different types of GF flours such as rice flour, maize flour, and soy flour because they found that blending various types of flour significantly increased the nutritional profile especially with the addition of up to $40 \%$ of soy flour and demonstrated no undesirable effect on sensory properties of the final products. Besides, the previous study performed by Inyang et al. (2017) has reported that the increment in the percentage of red kidney bean flour up to $40 \%$ into the composite of unripe banana-sweet potato flour caused a decrease in bulk density, water absorption capacity and swelling index but unfortunately increased the oil absorption and foaming capacity. In addition, in terms of the physical properties, the incorporation of red kidney bean flour had improved the thickness although, decreased the weight, length, width and spread ratio of the GF biscuits. On the other hand, Korus et al. (2017) carried out a study on the effect of cornflour and hemp flour in the partial substitution of cornflour. Generally, both of the studied flours effectively increased the nutritional value compared to GF biscuits made from $100 \%$ corn flour and also enhanced the hydration properties of mixtures and oil absorption capacity. Another study on the development of GF biscuits from peanut-millet composite flour carried by Alhassan et al. (2019) found that the studied flours effectively increased the nutritional data in terms of the protein and ash content as compared to wheat flour biscuits plus the final products was overall acceptable for its sensory evaluation.

Moreover, the earlier studies performed by Tosi et al. (1996) and Hozova et al. (1997) have reported that whole amaranth flour is not only capable of producing GF biscuits with high protein content but also high energy value as compared to the average GF biscuits. In addition, according to the study by Alvarez-Jubete et al. (2010), the crispness of GF biscuits made from buckwheat flour possessed the highest level of crispness then followed by quinoa and amaranth flour plus, the most preferred GF biscuits are the formulation containing buckwheat and amaranth flour. Hence, by observing the trend of research, it can be concluded that early studies mostly focused on the usage of a single type of GF flour as compared to recent studies. Table 1 presents the summary of the effect of different GF flours on bread, cake and biscuit.

\section{Functional ingredients to improve gluten-free bakery products}

\subsection{Hydrocolloids}

Hydrocolloids are typically used as a thickening and gelling agent in order to aid the quality and shelf life of food products (Woomer and Adedeji, 2020). The most typical hydrocolloids used in the development of GF bread are hydroxypropyl methylcellulose (HPMC) and xanthan gum (XG) (Masure et al., 2016; Roman et al., 2019). This is due to the capability of HPMC in improving batter consistency, bread textural properties (Morreale et al., 2018) and generating higher specific volume for GF bread (Belorio and Gómez, 2020). Whereas the addition of XG potentially yielding a good crumb structure and higher specific volume in the final products (Vidaurre-Ruiz et al., 2019). Additionally, XG is also capable of decreasing the hardness and enhancing elasticity in both fresh and stored bread (Mohammadi et al., 2014). However, other hydrocolloids such as carboxymethyl cellulose (CMC), guar gum, pectin and agarose have been used as gluten substitutes in the manufacturing of GF bread which provided promising final bread quality (Wang et al., 2017)

Apart from that, hydrocolloids are useful in the making of GF cakes in order to improve the texture and outcome of final products (Preichardt et al., 2011). Over recent years, there were a lot of studies conducted on the application of various hydrocolloids in the development of GF cakes; however, XG was constantly studied in most of the research performed. Generally, it has been found that $\mathrm{XG}$ capable of increasing the firmness and chewiness of GF cakes (Andrade et al., 2018), stabilized dispersions due to the capability to prevent particle sedimentation (Fitzpatrick et al., 2013) and potentially improved the viscoelasticity of batter (Itthivadhanapong et al., 2016). Anyway, other hydrocolloids like carrageenan, locust bean gum, arabic gum, HPMC, and guar gum are also analysed in the study of Itthivadhanapong et al. (2016) and Meng and Kim (2020a). Mostly, those hydrocolloids are capable of enhancing the specific volume and softness of GF cakes.

In the case of GF biscuits, although gluten does not play a primary role in the formulation of this product, it has been observed that lack of gluten in biscuits generally lead to low quality (Engleson and Atwell, 2008). Therefore, to obtain better quality, hydrocolloids 
Table 1. Summary of different types of GF flours used in bread, cakes, and biscuits

\begin{tabular}{|c|c|c|c|}
\hline Bakery products & Gluten-free flours & Effect in bakery products & References \\
\hline \multirow[t]{8}{*}{ Bread } & GF cereals & & \\
\hline & Millet & - Undesirable effect due to astringent flavour & Habiyaremye et al. (2017) \\
\hline & Sorghum & - Small volume; brittle crumb bread & Schober et al. (2005) \\
\hline & Pseudo-cereals & & \\
\hline & Amaranth & $\begin{array}{l}\text { - Increased water holding capacity, viscoelasticity, } \\
\text { micronutrients profile }\end{array}$ & Liu et al. (2019) \\
\hline & Buckwheat & $\begin{array}{l}\text { - Increased insoluble fibre, specific volume, cell } \\
\text { circularity, cell numbers and no negative effect on } \\
\text { sensory properties }\end{array}$ & Southgate et al. (2017) \\
\hline & Legumes & & \\
\hline & $\begin{array}{l}\text { Chickpea } \\
\text { Soybean }\end{array}$ & $\begin{array}{l}\text { - Improved nutrient content; decreased in volume and } \\
\text { produced poor texture } \\
\text { - Improved quality, sensory properties, and nutritional } \\
\text { content }\end{array}$ & $\begin{array}{l}\text { Yamsaengsung et al. (2010); Ragaee } \\
\text { et al. }(2011) ; \text { Xiao et al. }(2014) \\
\text { Taghdir } \text { et al. }(2017)\end{array}$ \\
\hline
\end{tabular}

Cakes GF cereals

\begin{tabular}{|c|c|c|}
\hline $\begin{array}{l}\text { Finest particles } \\
\text { rice flour }\end{array}$ & $\begin{array}{l}\text { - Produced batters with low specific volume, small, } \\
\text { uniform bubble }\end{array}$ & de la Hera et al. (2012) \\
\hline $\begin{array}{l}\text { Black glutinous } \\
\text { rice }\end{array}$ & $\begin{array}{l}\text { - Increased specific gravity, firmness, gumminess, } \\
\text { chewiness }\end{array}$ & $\begin{array}{l}\text { Itthivadhanapong and Sangnark, } \\
\text { (2016) }\end{array}$ \\
\hline Buckwheat & $\begin{array}{l}\text { - Improve the uniformity and symmetry index of } \\
\text { cakes; decreased softness of the crumb (15\% to } 20 \% \text { of } \\
\text { buckwheat flour) }\end{array}$ & Levent and Bilgiçli (2011) \\
\hline
\end{tabular}

Legumes

\begin{tabular}{lll}
\hline Lupin & $\bullet$ Enhanced volume and softness of cakes (20\% of & Levent and Bilgiçli (2011) \\
& $\begin{array}{l}\text { lupin flour); improved the crust yellowness and } \\
\text { nutrient contents }\end{array}$ & \\
- Decreased the hardness; slow down the rate of & Dhen et al. (2016) \\
& staling & \\
\hline
\end{tabular}

Pseudo-cereals

Quinoa $\quad$ Enhanced the batter stability, homogeneity, mechanical strength, nutritional, sensory properties, specific volume, and viscosity of the batter $(50 \%$ of quinoa flour)

- Increased specific volume, porosity; improved the moisture content $(20 \%$ amaranth flour $+0.5 \%$ mandab gum)

Amaranth

\author{
Bozdogan et al. (2019); Shevkani et \\ al. (2015)
}

Estiri and Naghipour (2019)

\section{Biscuits Composite}

\begin{tabular}{lll}
\hline Rice, maize and & $\bullet$ Increased the nutritional content; no undesirable & Man et al. (2014) \\
soy & effect on sensory properties
\end{tabular}

Red kidney bean, - Decreased bulk density, water absorption capacity, Inyang et al. (2017)

unripe banana and swelling index; increased the oil absorption and

sweet potato foaming capacity; improved thickness; decreased the weight, length, width and spread ratio $(40 \%$ red kidney bean flour)

Acorn and hemp - Increased the nutritional value; enhanced the

Korus et al. (2017) hydration properties of mixtures and oil absorption capacity

Peanut and millet - Increased protein and ash content; acceptable for its Alhassan et al. (2019) sensory evaluation.

Non-composite

\begin{tabular}{lll}
\hline Amaranth & $\bullet$ Produced high protein and energy content biscuits & $\begin{array}{l}\text { Tosi et al. (1996); Hozova et al. } \\
(1997) \\
\text { Alvarez-Jubete } \text { et al. }(2010)\end{array}$ \\
Buckwheat & $\bullet$ Greatest crispness & A
\end{tabular}


are used as an alternative way to achieve the desired quality. Basically, XG is one of the most incorporated hydrocolloids in the development of GF biscuits, followed by guar gum and tragacanth gum (TG). The study performed by Thejasri et al. (2017) reported that those hydrocolloids ( $\mathrm{XG}$, guar gum and $\mathrm{TG}$ ) have increased the sensory qualities, moisture content, diameter, thickness, weight, and lowered the fracture strength properties of GF biscuits. Last but not least, arabic gum, carrageenan and HPMC also have been studied and found capable of improving certain quality properties (Sarabhai et al., 2017).

\subsection{Protein}

The addition of protein-based ingredients is capable of improving the nutritional profile, functional properties and eating quality of final products (Deora et al., 2014). In general, soy protein isolates (SPI) and egg white are common protein sources that are usually studied in the formulation of GF bread. It has been reported that SPI leads to lower volume and dense crumb structures (Horstmann et al., 2017). According to Masure et al. (2019), batters added with SPI possess a high viscosity and poor stabilization of gas cells resulting in low volume and non-uniform bread crumb structure. Whereas the incorporation of egg whites possesses strong, cohesive behaviour, high foaming capacity and capability to stabilize the formation of gas bubbles during bread making (Han et al., 2019). On the other hand, several studies performed by Horstmann et al. (2017) and Han et al. (2019) found that egg whites have the ability to increase bread softness as well as the specific volume of GF bread. Apart from that, other protein sources such as lupin, carob, pea, and potato also have been investigated by Horstmann et al. (2017), in conjunction with the study, only the incorporation of carob, lupin, and pea present GF bread with higher volume, larger cell pores and softer bread crumb.

Besides, in the development of GF cakes, whey protein concentrate, and egg white protein are popular among the other functional ingredients. Sahagún et al. (2018) and Ammar et al. (2020) have reported that both of the animal protein sources capable of improving volume, springiness, cohesiveness with low baking loss, nonetheless both of the protein sources increased the hardness of the final products. Apart from that, it has been found that animal proteins are more effective in enhancing springiness and cohesiveness as compared to plant protein (Sahagún et al., 2018). Nevertheless, the study performed by Bravo-Núñez et al. (2020) discovered that the combination between the egg white and whey protein had increased the density of cake batters due to the antagonistic effect in emulsifying capacity and stability. However, other protein sources such as marine fish collagen have been reported capable of enhancing cell density, specific volume, springiness, and decreased hardness of GF rice cakes (Meng and Kim, 2020b).

On the other hand, the effect of the addition of protein in GF biscuits has also been studied over the past years. In general, the most applied protein ingredients in GF biscuits are soy protein and canola protein due to the efficient protein content that could provide beneficial effects to the final products (Gerzhova et al., 2016). Aly and Saleem (2015) reported that soy protein successfully increased the diameter, thickness, and volume even though, decreasing the specific volume of the final products. Moreover, the increment of soy protein percentage will lead to an improvement in the hardness and adhesiveness of GF biscuits. Likewise, canola protein also has the capability of increasing the diameter and thickness which indicates having a good gas holding capacity of dough, nevertheless this protein decreased the spread ratio and hardness of biscuits (Gerzhova et al., 2016). Besides, the addition of other proteins in GF biscuits could affect the quality of the final product, to be specific such as milk protein (Gallagher et al., 2005) and safflower protein isolate (Ordorica-Falomir et al., 1991). Overall, the findings on the effect of protein as functional ingredients in GF biscuits are still scarce.

\subsection{Enzymes}

Enzymes have been useful in the baking industry because of their ability in modifying and enhancing the functional, nutritional, and sensory properties of bakery products. Bender and Schönlechner (2020) predicted that cross-linking enzymes such as transglutaminase (TGase) are the most popular enzymes utilized in the development of GF bread. This is due to the potential of TGase in improving the viscoelasticity behaviour of dough by enhancing the ability to retain gases resulting in good expansion, higher volume, and softer crumb (Gusmão et al., 2019; Manhivi et al., 2020). Besides, another common enzyme used in baking is the protease enzyme. Generally, proteases can enhance the gas holding capacity and bread quality, to be a specific increasing volume of bread and crumb springiness while decreasing hardness, chewiness, and cohesiveness of the crumb (Azizi et al., 2020; Sarabhai et al., 2020). Furthermore, other enzymes such as $\alpha$-amylase and cyclodextrin glycosyltransferase (CGTase) are the enzymes that are rarely used in GF baking. Both enzymes serve the function of extending the process of retrogradation, starch hydrolysing and increased shelf life of GF bread (Gujral et al., 2003). However, both enzymes are capable of affecting the quality of final products such as softening crumbs and also increase the volume of bread (Basso et al., 2015).

Apart from that, enzymes are also incorporated into GF cakes. Similarly, TGase is the most studied enzyme 
in the development of GF cakes. Saeidi et al. (2018) reported that the addition of TGase had increased the porosity of the cell, nevertheless decreased the volume of GF cakes. In contrast, Yildiz and Dogan (2014) reported that TGase significantly improved the cake volume. This might be due to different concentrations used between those two studies, as Yildiz and Dogan (2014) mentioned that a higher concentration of TGase would lead to a decrease in cake volume. In addition, another study conducted by Rahim and Nouri (2020) evaluated that TGase can increase the adhesiveness as well as the hardness of GF cakes. Moreover, other enzymes such as cellulase and hemicellulase were analysed by Aghaesmaeili et al. (2020), and it has been reported that hemicellulase was effective in the improvement of cohesiveness plus, both of the enzymes can increase the water absorption ability in GF sponge cakes. However, lipase is also capable of providing a positive effect on the final product, such as maintaining and improving the softness of cakes (Colakoglu and Özkaya, 2012).

As for GF biscuits, Altındağ et al. (2015) have evaluated the effect of TGase in the development of semi -sweet GF biscuits. It has been found that TGase increased the fracturability value and moisture content of final products. According to Beck et al. (2011), the increased moisture level is due to the deamination of glutamine which produces glutamic acid residues, a negatively charged group that induces the ability of protein in water binding. Nonetheless, TGase has been reported capable of decreasing the hardness of final products (Altındağ et al., 2015). In general, the study on the application of enzymes in the development of GF biscuits seems very limited. This might be due to the application of enzymes that are more reliable in other GF bakery products such as bread and cakes.

\section{Novel technologies approach in gluten-free bakery products}

High-pressure processing (HPP) is a non-thermal process that consists of treating food with high pressures to modify functional properties of starch and protein in order to create novel structures and textures (Vallons et al., 2011). HPP basically can improve the formation of protein networks (Kieffer et al., 2007) and capable of inducing starch gelatinization consequently increased batter viscoelasticity (Vallons et al., 2011). The application of HPP in the range of 100 to $1000 \mathrm{MPa}$ has been investigated and could alter the functional properties of GF flours (Ahmed et al., 2007). In fact, swelling properties induced by HPP are influenced by factors such as applied pressure, time, the temperature of treatment, type, and concentration of starch (Stolt et al., 2000). On the other hand, HPP is also capable of enhancing bread crumb volume (Hüttner, 2010) and slowing down the staling process (Vallons et al., 2011).
Overall, the findings on the effect of HPP treatments are still limited; therefore, further studies on this method are expected in the future in order to optimize the impact of this treatment on different GF flours and other GF bakery products.

Furthermore, sourdough fermentation is considered one of the novel technological approaches in improving the functional properties of GF products. Basically, sourdough is made from a mixture of flour, water and other ingredients which are fermented by yeasts and lactic acid bacteria (LAB) (Capriles and Arêas, 2014). It has been well known that this process could enhance the rheological properties of batters or dough (Jekle et al., 2010; Nami et al., 2019), bread's volume and texture (Axel et al., 2015; Aguilar et al., 2016), nutritional values (Svensson et al., 2010) and prolong the shelf life of bread (Lacaze et al., 2007). The positive effects presented by sourdough fermentation generally associated with the by-products produced by LAB during the fermentation process, to be specific volatile and antimicrobial compounds, lactic acid, and exopolysaccharide (EPS) (Moroni et al., 2009). EPS can be classified as hydrocolloid replacer, which possessed the ability to improve the rheological properties of dough (Galle et al., 2012). With the presence of by-products, dough properties can be enhanced by modifying the main structure building components such as starch and arabinoxylans, increased the solubility of the protein, and activating endogenous enzymes such as proteases and amylase which lead to the softer crumb structure (Bender and Schönlechner, 2020).

On the other hand, extrusion treatment is another method that can help to enhance the quality of GF bakery products. It has been shown that extrusion processing of starch-based food will result in a transformation in the functional properties in terms of rheological behaviour of flour slurry, water solubility (WS) and water absorption index (WAI) (Jafari et al., 2017). In conjunction, several studies have proven the effect of extruded quinoa, ricecorn and buckwheat flour in the development of GF bread lead to an increase in a specific volume and decreased bread firmness (Murgueytio and Santacruz, 2020), improved WAI, WS and damaged starch (Yaghbani et al., 2019) and increased the formation of the starch network (Cheng et al., 2020), respectively. Nevertheless, extrusion treatment also reported to have a positive impact on cookie quality (Paesani et al., 2020a) and helps in stabilizing foam in biscuits dough (Lisovska et al., 2020). Conversely, Paesani et al. (2020b) found that this treatment caused a detrimental effect in GF layer cakes by decreasing the specific volume and increasing the hardness of cakes. 


\section{Conclusion}

As to be expected, the demand for GF food keeps on growing in the future. Although the development of GF food remains a technological challenge, research continues to discover new strategies and approaches that may provide a better solution to GF product development. As described in this review, single or combination usage of GF flours consist of GF cereals, pseudocereals and legumes are applicable in the development of GF bread, cakes and biscuits, even though these ingredients cannot completely replace and fully imitate the outcome of non-gluten free bakery products.

However, in the present articles, recent studies have shown that the manufacturing of GF bakery products presented promising impact with the aid of functional ingredients such as hydrocolloids, protein and enzymes in fulfilling some deficiencies in GF products to obtain good physical and eating qualities. Apart from ingredients, the application of novel technologies delivers further solutions for the production of good quality GF products. High-pressure treatment exhibits potential in the formation of protein network and starch gelatinization, whereas sourdough fermentation could enhance the rheological properties of batters or dough, bread's volume and texture, nutritional values as well as prolong the shelf life of bread, lastly extrusion technology that capable of improving starch gelatinization which leads to better functional properties and structural attributes.

Therefore, future efforts should be more focused on novel technologies strategies, especially on the highpressure process, and extrusion technology seems both processes are promising in terms of product quality and time efficiency. Yet, findings are still very limited, particularly in gluten-free bakery products other than bread.

\section{Conflict of interest}

The authors declare no conflicts of interest.

\section{Acknowledgements}

The authors acknowledge the financial support by the Universiti Malaysia Sabah (UMS) (SDK0137-2020).

\section{References}

Aghaesmaeili, E., Abbasi, H. and Fazel, M. (2020). Effects of cellulase, hemicellulase and lecithin on qualitative properties of gluten-free sponge cakes based on flaxseed meal and rice flour. Iranian Journal of Nutrition Sciences and Food Technology, 15(3), 43-58.
Aguilar, N., Albanell, E., Miñarro, B. and Capellas, M. (2016). Chestnut flour sourdough for gluten-free bread making. European Food Research and Technology, 242(10), 1795-1802. https:// doi.org/10.1007/s00217-016-2679-z

Ahmed, J., Ramaswamy, H.S., Ayad, A., Alli, I. and Alvarez, P. (2007). Effect of high-pressure treatment on rheological, thermal and structural changes in Basmati rice flour slurry. Journal of Cereal Science, 46(2), 148-156. https://doi.org/10.1016/ j.jcs.2007.01.006

Alhassan, M.W., Ojangba, T. and Amagloh, F.K. (2019). Development of gluten-free biscuit from peanutpearl millet composite flour. American Journal of Food Science and Technology, 7(2), 40-44.

Altındağ, G., Certel, M., Erem, F. and İlknur Konak, Ü. (2015). Quality characteristics of gluten-free cookies made of buckwheat, corn, and rice flour with/without transglutaminase. Food Science and Technology International, 21(3), 213-220. https:// doi.org/10.1177/1082013214525428

Alvarez-Jubete, L., Arendt, E.K. and Gallagher, E. (2010). Nutritive value of pseudocereals and their increasing use as functional gluten-free ingredients. Trends in Food Science and Technology, 21(2), 106113. https://doi.org/10.1016/j.tifs.2009.10.014

Aly, M.M. and Seleem, H.A. (2015). Gluten-free flat bread and biscuits production by cassava, extruded soy protein and pumpkin powder. Food and Nutrition Sciences, 6(7), 660-674. https:// doi.org/10.4236/fns.2015.67069

Ammar, I., Gharsallah, H., Brahim, A.B., Attia, H., Ayadi, M.A., Hadrich, B. and Felfoul, I. (2021). Optimization of gluten-free sponge cake fortified with whey protein concentrate using mixture design methodology. Food Chemistry, 343, 128457. https:// doi.org/10.1016/j.foodchem.2020.128457

Andrade, F.J.E.T., Albuquerque, P.B.S., Moraes, G.M.D., Farias, M.D.P., Teixeira-Sá, D.M.A., Vicente, A.A. and Carneiro-da-Cunha, M.G. (2018). Influence of hydrocolloids (galactomannan and xanthan gum) on the physicochemical and sensory characteristics of gluten-free cakes based on fava beans (Phaseolus lunatus). Food and Function, 9 (12), 6369-6379. https://doi.org/10.1039/ C8FO01448E

Axel, C., Röcker, B., Brosnan, B., Zannini, E., Furey, A., Coffey, A. and Arendt, E.K. (2015). Application of Lactobacillus amylovorus DSM19280 in gluten-free sourdough bread to improve the microbial shelf life. Food Microbiology, 47, 36-44. https:// doi.org/10.1016/j.fm.2014.10.005 
Azizi, S., Azizi, M.H., Moogouei, R. and Rajaei, P. (2020). The effect of Quinoa flour and enzymes on the quality of gluten-free bread. Food Science and Nutrition, 8(5), 2373-2382. https://doi.org/10.1002/ fsn3.1527

Basso, F.M., Mangolim, C.S., Aguiar, M.F.A., Monteiro, A.R.G., Peralta, R.M. and Matioli, G. (2015). Potential use of cyclodextrin-glycosyltransferase enzyme in bread-making and the development of gluten-free bread with pinion and corn flours. International Journal of Food Sciences and Nutrition, 66(3), 275-281. https:// doi.org/10.3109/09637486.2015.1007450

Beck, M., Jekle, M., Selmair, P.L., Koehler, P. and Becker, T. (2011). Rheological properties and baking performance of rye dough as affected by transglutaminase. Journal of Cereal Science, 54(1), 29-36. https://doi.org/10.1016/j.jcs.2011.01.012

Belorio, M. and Gómez, M. (2020). Effect of hydration on gluten-free bread made with hydroxypropyl methylcellulose in comparison with Psyllium and Xanthan gum. Foods, 9(11), 1548. https:// doi.org/10.3390/foods 9111548

Bender, D. and Schönlechner, R. (2020). Innovative approaches towards improved gluten-free bread properties. Journal of Cereal Science, 91, 102904. https://doi.org/10.1016/j.jcs.2019.102904

Bozdogan, N., Kumcuoglu, S. and Tavman, S. (2019). Investigation of the effects of using quinoa flour on gluten-free cake batters and cake properties. Journal of Food Science and Technology, 56(2), 683-694. https://doi.org/10.1007/s13197-018-3523-1

Bravo-Núñez, Á., Sahagún, M., Bravo-Núñez, A. and Gómez, M. (2020). Optimization of protein-enriched gluten-free layer cakes using a mixture design. International Journal of Food Science and Technology, 55(5), 2171-2178. https:// doi.org/10.1111/ijfs.14470

Brockow, K., Kneissl, D., Valentini, L., Zelger, O., Grosber, M., Kugler, C. and Ring, J. (2015). Using a gluten oral food challenge protocol to improve diagnosis of wheat-dependent exercise-induced anaphylaxis. Journal of Allergy and Clinical Immunology, 135(4), 977-984. https:// doi.org/10.1016/j.jaci.2014.08.024

Capriles, V.D. and Arêas, J.A.G. (2014). Novel approaches in gluten-free breadmaking: interface between food science, nutrition, and health. Comprehensive Reviews in Food Science and Food Safety, 13(5), 871-890. https://doi.org/10.1111/15414337.12091

Cheng, W., Gao, L., Wu, D., Gao, C., Meng, L., Feng, X. and Tang, X. (2020). Effect of improved extrusion cooking technology on structure, physiochemical and nutritional characteristics of physically modified buckwheat flour: Its potential use as food ingredients. LWT - Food Science and Technology, 133, $\quad 109872 . \quad$ https://doi.org/10.1016/ j.lwt.2020.109872

Colakoglu, A.S. and Özkaya, H. (2012). Potential use of exogenous lipases for DATEM replacement to modify the rheological and thermal properties of wheat flour dough. Journal of Cereal Science, 55(3), 397-404. https://doi.org/10.1016/j.jcs.2012.02.001

Croall, I.D., Trott, N., Rej, A., Aziz, I., O’Brien, D.J., George, H.A. and Hadjivassiliou, M. (2019). A population survey of dietary attitudes towards Gluten. Nutrients, 11(6), $1276 . \quad$ https:// doi.org/10.3390/nu11061276

de la Hera, E., Martinez, M., Oliete, B. and Gómez, M. (2012). Influence of flour particle size on quality of gluten-free rice cakes. Food and Bioprocess Technology, 6(9), 2280-2288. https:// doi.org/10.1007/s11947-012-0922-6

Deora, N.S., Deswal, A. and Mishra, H.N. (2014). Alternative approaches towards gluten-free dough development: recent trends. Food Engineering Reviews, 6(3), 89-104. https://doi.org/10.1007/ s12393-014-9079-6

Dhen, N., Román, L., Rejeb, I.B., Martínez, M.M., Garogouri, M. and Gómez, M. (2016). Particle size distribution of soy flour affecting the quality of enriched gluten-free cakes. LWT - Food Science and Technology, 66, 179-185. https://doi.org/10.1016/ j.lwt.2015.10.032

Engleson, J. and Atwell, B. (2008). Gluten-free product development. Cereal Foods World, 53(4), 180-185. https://doi.org/10.1094/CFW-53-4-0180

Estiri, S.H. and Naghipour, F. (2019). Effect of Rice Flour Replacement by Amaranth as pseudocereals native gum (Eruca sativa) addition on improvement of quantitative and qualitative properties of gluten free cake. Food Science and Technology, 16(91), 4556.

Fitzpatrick, P., Meadows, J., Ratcliffe, I. and Williams, P.A. (2013). Control of the properties of xanthan/ glucomannan mixed gels by varying xanthan fine structure. Carbohydrate Polymers, 92(2), 10181025. https://doi.org/10.1016/j.carbpol.2012.10.049

Forbes, G.M. (2015). If only my celiac patients and I knew that. Clinical Gastroenterology and Hepatology, 13(3), 614-615. https://doi.org/10.1016/ j.cgh.2014.08.022

Gallagher, E., Kenny, S. and Arendt, E.K. (2005). 
Impact of dairy protein powders on biscuit quality. European Food Research and Technology, 221(3-4), 237-243. https://doi.org/10.1007/s00217-005-1140-5

Galle, S., Schwab, C., Dal Bello, F., Coffey, A., Gänzle, M.G. and Arendt, E.K. (2012). Influence of in-situ synthesized exopolysaccharides on the quality of gluten-free sorghum sourdough bread. International Journal of Food Microbiology, 155(3), 105-112. https://doi.org/10.1016/j.ijfoodmicro.2012.01.009

Gerzhova, A., Mondor, M., Benali, M. and Aider, M. (2016). Incorporation of canola proteins extracted by electroactivated solutions in gluten-free biscuit formulation of rice-buckwheat flour blend: assessment of quality characteristics and textural properties of the product. International Journal of Food Science and Technology, 51(3), 814-827. https://doi.org/10.1111/ijfs.13034

Gujral, H.S., Guardiola, I., Carbonell, J.V. and Rosell, C.M. (2003). Effect of cyclodextrinase on dough rheology and bread quality from rice flour. Journal of Agricultural and Food Chemistry, 51(13), 38143818. https://doi.org/10.1021/jf034112w

Gujral, N., Freeman, H.J. and Thomson, A.B. (2012). Celiac disease: prevalence, diagnosis, pathogenesis and treatment. World Journal of Gastroenterology, 18(42), 6036- 6059. https://doi.org/10.3748/ wjg.v18.i42.6036

Gusmão, T.A.S., de Gusmao, R.P., Moura, H.V., Silva, H.A., Cavalcanti-Mata, M.E.R.M. and Duarte, M.E.M. (2019). Production of prebiotic gluten-free bread with red rice flour and different microbial transglutaminase concentrations: modelling, sensory and multivariate data analysis. Journal of Food Science and Technology, 56(6), 2949-2958. https:// doi.org/10.1007/s13197-019-03769-8

Habiyaremye, C., Matanguihan, J.B., D’Alpoim Guedes, J., Ganjyal, G.M., Whiteman, M.R., Kidwell, K.K. and Murphy, K.M. (2017). Proso millet (Panicum miliaceum L.) and its potential for cultivation in the Pacific Northwest, US: A review. Frontiers in Plant Science, 7, 1961. https://doi.org/10.3389/ fpls.2016.01961

Han, A., Romero, H.M., Nishijima, N., Ichimura, T., Handa, A., Xu, C. and Zhang, Y. (2019). Effect of egg white solids on the rheological properties and bread making performance of gluten-free batter. Food Hydrocolloids, 87, 287-296. https:// doi.org/10.1016/j.foodhyd.2018.08.022

Horstmann, S.W., Foschia, M. and Arendt, E.K. (2017). Correlation analysis of protein quality characteristics with gluten-free bread properties. Food and Function, 8(7), 2465-2474. https://doi.org/10.1039/ C7FO00415J
Hozova, B., Buchtová, V., Dodok, L. and Zemanovič, J. (1997). Microbiological, nutritional and sensory aspects of stored amaranth biscuits and amaranth crackers. Food/Nahrung, 41(3), 155-158. https:// doi.org/10.1002/food.19970410308

Hüttner, E.K. and Arendt, E.K. (2010). Recent advances in gluten-free baking and the current status of oats. Trends in Food Science and Technology, 21(6), 303312. https://doi.org/10.1016/j.tifs.2010.03.005

Inyang, U., Udofia, C. and Ukwo, S. (2017). Functional properties and quality characteristics of gluten free biscuits made from unripe banana and sweet potato composite flour supplemented with red kidney bean flour. Journal of Advances in Food Science and Technology, 4(3), 100-108.

Itthivadhanapong, P. and Sangnark, A. (2016). Effects of substitution of black glutinous rice flour for wheat flour on batter and cake properties. International Food Research Journal, 23(3), 1190.

Jafari, M., Koocheki, A. and Milani, E. (2017). Effect of extrusion cooking on chemical structure, morphology, crystallinity and thermal properties of sorghum flour extrudates. Journal of Cereal Science, 75, 324-331. https://doi.org/10.1016/ j.jcs.2017.05.005

Jekle, M., Houben, A., Mitzscherling, M. and Becker, T. (2010). Effects of selected lactic acid bacteria on the characteristics of amaranth sourdough. Journal of the Science of Food and Agriculture, 90(13), 2326-2332. https://doi.org/10.1002/jsfa.4091

Kieffer, R., Schurer, F., Köhler, P. and Wieser, H. (2007). Effect of hydrostatic pressure and temperature on the chemical and functional properties of wheat gluten: Studies on gluten, gliadin and glutenin. Journal of Cereal Science, 45(3), 285292. https://doi.org/10.1016/j.jcs.2006.09.008

Korus, A., Gumul, D., Krystyjan, M., Juszczak, L. and Korus, J. (2017). Evaluation of the quality, nutritional value and antioxidant activity of glutenfree biscuits made from corn-acorn flour or cornhemp flour composites. European Food Research and Technology, 243(8), 1429-1438. https:// doi.org/10.1007/s00217-017-2853-y

Kraithong, S., Lee, S. and Rawdkuen, S. (2018). Physicochemical and functional properties of Thai organic rice flour. Journal of Cereal Science, 79, 259 -266. https://doi.org/10.1016/j.jcs.2017.10.015

Lacaze, G., Wick, M. and Cappelle, S. (2007). Emerging fermentation technologies: development of novel sourdoughs. Food Microbiology, 24(2), 155-160. https://doi.org/10.1016/j.fm.2006.07.015

Levent, H. and Bilgiçli, N. (2011). Effect of gluten-free 
flours on physical properties of cakes. Journal of Food Science and Engineering, 1(5), 354.

Lisovska, T., Stadnik, I., Piddubnyi, V. and Chorna, N. (2020). Effect of extruded corn flour on the stabilization of biscuit dough for the production of gluten-free biscuit. Ukrainian Food Journal, 9(1), 159-174. https://doi.org/10.24263/2304-974X-20209-1-14

Liu, S., Chen, D. and Xu, J. (2019). Characterization of amaranth and bean flour blends and the impact on quality of gluten-free bread. Journal of Food Measurement and Characterization, 13(2), 14401450. https://doi.org/10.1007/s11694-019-00060-4

Man, S.M., Paucean, A. and Muste, S. (2014). Preparation and quality evaluation of gluten-free biscuits. Bulletin UASVM Food Science and Technology, 71(1), 38-44. https://doi.org/10.15835/ buasvmen-fst: 10080

Manhivi, V.E., Amonsou, E.O. and Kudanga, T. (2020). Transglutaminase and tyrosinase as potential crosslinking tools for the improvement of rheological properties of gluten-free amadumbe dough. International Journal of Food Science and Technology, 55(6), 2399-2407. https:// doi.org/10.1111/ijfs.14489

Masure, H.G., Fierens, E. and Delcour, J.A. (2016). Current and forward looking experimental approaches in gluten-free bread making research. Journal of Cereal Science, 67, 92-111. https:// doi.org/10.1016/j.jcs.2015.09.009

Masure, H.G., Wouters, A.G., Fierens, E. and Delcour, J.A. (2019). Impact of egg white and soy proteins on structure formation and crumb firming in gluten-free bread. Food Hydrocolloids, 95, 406-417. https:// doi.org/10.1016/j.foodhyd.2019.04.062

Meng, L.W. and Kim, S.M. (2020a). Effects of different hydrocolloids on physicochemical properties of high -moisture fermented rice cake during storage. Cereal Chemistry, 19(2), 128-135. https://doi.org/10.1111/ jfpp. 14857

Meng, L.W. and Kim, S.M. (2020b). Effects of different proteins on the rheological properties of rice batter and characteristics of fermented rice cakes. Journal of Food Processing and Preservation, 44(11), e14857

Mohammadi, M., Sadeghnia, N., Azizi, M.H., Neyestani, T.R. and Mortazavian, A.M. (2014). Development of gluten-free flat bread using hydrocolloids: Xanthan and CMC. Journal of Industrial and Engineering Chemistry, 20(4), 1812-1818. https:// doi.org/10.1016/j.jiec.2013.08.035

Moroni, A.V., Dal Bello, F. and Arendt, E.K. (2009).
Sourdough in gluten-free bread-making: an ancient technology to solve a novel issue? Food Microbiology, 26(7), 676-684. https:// doi.org/10.1016/j.fm.2009.07.001

Morreale, F., Garzón, R. and Rosell, C.M. (2018). Understanding the role of hydrocolloids viscosity and hydration in developing gluten-free bread. A study with hydroxypropylmethylcellulose. Food Hydrocolloids, 77, 629-635. https://doi.org/10.1016/ j.foodhyd.2017.11.004

Murgueytio, E. and Santacruz, S. (2020). Volume, firmness and crumb characteristics of gluten-free bread based on extruded quinoa flour and lactic acid. Brazilian Journal of Food Technology, 23, e2019220. https://doi.org/10.1590/1981-6723.22019

Nami, Y., Gharekhani, M., Aalami, M. and Hejazi, M.A. (2019). Lactobacillus-fermented sourdoughs improve the quality of gluten-free bread made from pearl millet flour. Journal of Food Science and Technology, 56(9), 4057-4067. https:// doi.org/10.1007/s13197-019-03874-8

Naqash, F., Gani, A., Gani, A. and Masoodi, F.A. (2017). Gluten-free baking: Combating the challenges-A review. Trends in Food Science and Technology, 66, 98-107. https://doi.org/10.1016/ j.tifs.2017.06.004

Ordorica-Falomir, C. and Paredes-Lopez, O. (1991). Effect of safflower protein isolates on cookie characteristics. International Journal of Food Science and Technology, 26(1), 39-43. https:// doi.org/10.1111/j.1365-2621.1991.tb01139.x

Ortiz, C., Valenzuela, R. and Lucero Alvarez, Y. (2017). Celiac disease, non-celiac gluten sensitivity and wheat allergy: comparison of 3 different diseases triggered by the same food. Revista Chilena de Pediatría, 88, 417-423. https://doi.org/10.4067/ S0370-41062017000300017

Paesani, C., Bravo-Núñez, Á. and Gómez, M. (2020a). Effect of extrusion of whole-grain maize flour on the characteristics of gluten-free cookies. LWT - Food Science and Technology, 132, 109931. https:// doi.org/10.1016/j.lwt.2020.109931

Paesani, C., Bravo-Núñez, Á. and Gómez, M. (2020b). Effect of stabilized wholegrain maize flours on the quality characteristics of gluten-free layer cakes. LWT - Food Science and Technology, 135, 109959. https://doi.org/10.1016/j.lwt.2020.109959

Preichardt, L.D., Vendruscolo, C.T., Gularte, M.A. and Moreira, A.D.S. (2011). The role of xanthan gum in the quality of gluten free cakes: improved bakery products for coeliac patients. International Journal of Food Science and Technology, 46(12), 2591-2597. https://doi.org/10.1111/j.1365-2621.2011.02788.x 
Ragaee, S., Guzar, I., Dhull, N. and Seetharaman, K. (2011). Effects of fiber addition on antioxidant capacity and nutritional quality of wheat bread. $L W T$ -Food Science and Technology, 44(10), 2147-2153. https://doi.org/10.1016/j.1wt.2011.06.016

Rahim, M.M. and Nouri, L. (2020). Incorporation of Sesamum indicum protein and transglutaminase into gluten-free rice flour cake: Assessment of physicochemical and sensory properties. Journal of Food Processing and Preservation, 44(9), e14660. https:// doi.org/10.1111/jfpp. 14660

Roman, L., Belorio, M. and Gomez, M. (2019). Glutenfree bread: The gap between research and commercial reality. Comprehensive Reviews in Food Science and Food Safety, 18(3), 690-702. https:// doi.org/10.1111/1541-4337.12437

Roszkowska, A., Pawlicka, M., Mroczek, A., Bałabuszek, K. and Nieradko-Iwanicka, B. (2019). Non-celiac gluten sensitivity: A review. Medicina, 55(6), 222. https://doi.org/10.3390/ medicina55060222

Saeidi, Z., Nasehi, B. and Jooyandeh, H. (2018). Optimization of gluten-free cake formulation enriched with pomegranate seed powder and transglutaminase enzyme. Journal of Food Science and Technology, 55(8), 3110-3118. https:// doi.org/10.1007/s13197-018-3236-5

Sahagún, M., Bravo-Núñez, Á., Báscones, G. and Gómez, M. (2018). Influence of protein source on the characteristics of gluten-free layer cakes. $L W T-$ Food Science and Technology, 94, 50-56. https:// doi.org/10.1016/j.1wt.2018.04.014

Sarabhai, S., Sudha, M. L. and Prabhasankar, P. (2017). Rheological characterization and biscuit making potential of gluten free flours. Journal of Food Measurement and Characterization, 11(3), 14491461. https://doi.org/10.1007/s11694-017-9524-3

Sarabhai, S., Tamilselvan, T. and Prabhasankar, P. (2020). Role of enzymes for improvement in glutenfree foxtail millet bread: It's effect on quality, textural, rheological and pasting properties. $L W T-$ Food Science and Technology, 137, 110365. https:// doi.org/10.1016/j.lwt.2020.110365

Schober, T.J., Bean, S.R., Boyle, D.L. and Park, S.H. (2008). Improved viscoelastic zein-starch doughs for leavened gluten-free bread: Their rheology and microstructure. Journal of Cereal Science, 48(3), 755-767. https://doi.org/10.1016/j.jcs.2008.04.004

Serrem, C.A., de Kock, H.L. and Taylor, J.R. (2011). Nutritional quality, sensory quality and consumer acceptability of sorghum and bread wheat biscuits fortified with defatted soy flour. International
Journal of Food Science and Technology, 46(1), 7483. https://doi.org/10.1111/j.13652621.2010.02451.x

Shevkani, K., Kaur, A., Kumar, S. and Singh, N. (2015). Cowpea protein isolates: functional properties and application in gluten-free rice muffins. $L W T$ - Food Science and Technology, 63(2), 927-933. https:// doi.org/10.1016/j.lwt.2015.04.058

Southgate, A.N.N., Scheuer, P.M., Martelli, M.F., Menegon, L. and de Francisco, A. (2017). Quality properties of a gluten-free bread with buckwheat. Journal of Culinary Science and Technology, 15(4), 339-348. doi.org/10.1080/15428052.2017.1289134

Stolt, M., Oinonen, S. and Autio, K. (2000). Effect of high pressure on the physical properties of barley starch. Innovative Food Science and Emerging Technologies, 1(3), 167-175. https://doi.org/10.1016/ S1466-8564(00)00017-5

Svensson, L., Sekwati-Monang, B., Lutz, D.L., Schieber, A. and Ganzle, M.G. (2010). Phenolic acids and flavonoids in nonfermented and fermented red sorghum (Sorghum bicolor (L.) Moench). Journal of Agricultural and Food Chemistry, 58(16), 92149220. https://doi.org/10.1021/jf101504v

Taghdir, M., Mazloomi, S. M., Honar, N., Sepandi, M., Ashourpour, M. and Salehi, M. (2017). Effect of soy flour on nutritional, physicochemical, and sensory characteristics of gluten-free bread. Food Science and Nutrition, 5(3), 439-445. https://doi.org/10.1002/ fsn3.411

Thejasri, V., Hymavathi, T. V. and Roberts, T.P.P. (2017). Sensory, physico-chemical and nutritional properties of gluten free biscuits formulated with quinoa (Chenopodium quinoa willd), foxtail millet (Setaria italica) and hydrocolloids. International Journal of Current Microbiology and Applied Sciences, 6(8), 1710-1721. https://doi.org/10.20546/ ijcmas.2017.608.205

Thiranusornkij, L., Thamnarathip, P., Chandrachai, A., Kuakpetoon, D. and Adisakwattana, S. (2019). Comparative studies on physicochemical properties, starch hydrolysis, predicted glycemic index of Hom Mali rice and Riceberry rice flour and their applications in bread. Food Chemistry, 283, 224231. https://doi.org/10.1016/j.foodchem.2019.01.048

Thiranusornkij, L., Thamnarathip, P., Chandrachai, A., Kuakpetoon, D. and Adisakwattana, S. (2018). Physicochemical properties of Hom Nil (Oryza sativa) rice flour as gluten free ingredient in bread. Foods, 7(10), 159. https://doi.org/10.3390/ foods 7100159 
Tomić, J.M., Torbica, A.M., Belović, M.M., Popović, L.M., Čakarević, J.C., Savanović, D.M. and MockoBlažek, K.A. (2018). Potential of pumpkin oil cake protein isolate in production of millet bread. Food and Feed Research, 45(2), 139-147. https:// doi.org/10.5937/FFR1802139T

Tosi, E.A., Ciappini, M.C. and Masciarelli, R. (1996). Utilization of whole amaranthus (Amaranthus cruentus) flour in the manufacture of biscuits for coeliacs. Alimentaria, 34(269), 49-51.

Trappey, E.F., Khouryieh, H., Aramouni, F. and Herald, T. (2015). Effect of sorghum flour composition and particle size on quality properties of gluten-free bread. Food Science and Technology International, 21(3), 188-202. https:// doi.org/10.1177/1082013214523632

Turkut, G.M., Cakmak, H., Kumcuoglu, S. and Tavman, S. (2016). Effect of quinoa flour on gluten-free bread batter rheology and bread quality. Journal of Cereal Science, 69, 174-181. https://doi.org/10.1016/ j.jcs.2016.03.005

Vallons, K.J., Ryan, L.A. and Arendt, E.K. (2011). Promoting structure formation by high pressure in gluten-free flours. LWT-Food Science and Technology, 44(7), 1672-1680. https:// doi.org/10.1016/j.lwt.2010.11.024

Vidaurre-Ruiz, J., Matheus-Diaz, S., Salas-Valerio, F., Barraza-Jauregui, G., Schoenlechner, R. and RepoCarrasco-Valencia, R. (2019). Influence of tara gum and xanthan gum on rheological and textural properties of starch-based gluten-free dough and bread. European Food Research and Technology, 245(7), 1347-1355. https://doi.org/10.1007/s00217019-03253-9

Wang, K., Lu, F., Li, Z., Zhao, L. and Han, C. (2017). Recent developments in gluten-free bread baking approaches: a review. Food Science and Technology, 37(Suppl. 1), 1-9. https://doi.org/10.1590/1678457x.01417

Woomer, J.S. and Adedeji, A.A. (2021). Current applications of gluten-free grains-a review. Critical Reviews in Food Science and Nutrition, 61(1), 1424. https://doi.org/10.1080/10408398.2020.1713724

Xiao, Y., Xing, G., Rui, X., Li, W., Chen, X., Jiang, M. and Dong, M. (2014). Enhancement of the antioxidant capacity of chickpeas by solid state fermentation with Cordyceps militaris SN-18. Journal of Functional Foods, 10, 210-222. https:// doi.org/10.1016/j.jff.2014.06.008

Yaghbani, M., Koocheki, A., Karimi, M., Mortazavi, S.A. and Milani, E. (2019). Effect of extrusion pretreatment conditions on physico-chemical properties of gluten-free flour blend of rice and corn. Journal of Innovative Food Technologies, 6(4), 521-532.

Yamsaengsung, R., Schoenlechner, R. and Berghofer, E. (2010). The effects of chickpea on the functional properties of white and whole wheat bread. International Journal of Food Science and Technology, 45(3), 610-620. https://doi.org/10.1111/ j.1365-2621.2009.02174.x

Yildiz, Ö. and Dogan, I.S. (2014). Optimization of gluten -free cake prepared from chestnut flour and transglutaminase: Response surface methodology approach. International Journal of Food Engineering, 10(4), 737-746. https:// doi.org/10.1515/ijfe-2014-0024 